\title{
JIMMBA
}

\section{The Effect Of Earnings per Share and Sales Growth pn Stock Prices in Sub-Sectors of Household Equipments Listed on BEI 2014-2019}

\author{
Jonatan Romeldo Pardomuan Hasiholan 1, Lorina Siregar Sudjiman ${ }^{2}$ \\ 1,2Universitas Advent Indonesia \\ Email: jonathansimanjuntak28@gmail.com¹, lorina.sudjiman@unai.edu²
}

\begin{tabular}{|c|c|}
\hline ARTICLE INFO & ABSTRACT \\
\hline $\begin{array}{l}\text { Article History: } \\
\text { Received: August } 31^{\text {st }} 2020 \\
\text { Accepted: September } 21^{\text {st }} \\
2020 \\
\text { Published: October } 22^{\text {nd }} 2020 \\
\text { Keywords: } \\
\text { Earning Per Share, Growth } \\
\text { Sales, Share Prices }\end{array}$ & $\begin{array}{l}\text { This study aims to determine the effect of Earning per Share (EPS) } \\
\text { and Sales Growth on stock prices. The population in this study are } \\
\text { all industrial companies in the household appliances sub-sector that } \\
\text { went public on the Indonesia Stock Exchange in the period } 2015 \text { to } \\
2019 \text {. Sampling in this study used a purposive sampling technique } \\
\text { with } 15 \text { corporate annual financial statement data. The analysis } \\
\text { technique in this study uses multiple linear regression to obtain a } \\
\text { comprehensive picture of the relationship between variables. } \\
\text { Earning per Share (EPS) has a positive but not significant effect on } \\
\text { the share prices of the household appliances sub-sector companies } \\
\text { listed on the Indonesia Stock Exchange in the period } 2015 \text { - } 2018 \text {. This } \\
\text { is evidenced by the regression coefficient X1 of } 1,554 \text { and a } \\
\text { significance value of } 0.105 \text {. This is evidenced by the regression } \\
\text { coefficient X1 - } 186,678 \text { and a significance value of } 0.447 \text {. So that if } \\
\text { there is an increase in sales growth in the household appliances sub- } \\
\text { sector, it will not affect the stock price. The result of the Adjusted R2 } \\
\text { test in this study is } 0.212 \text {. This shows that the share price of } \\
\text { household appliances sub-sector companies listed on the Indonesia } \\
\text { Stock Exchange in the period of } 2015 \text { - } 2019 \text { was influenced by } 21.2 \% \\
\text { by EPS and sales growth. }\end{array}$ \\
\hline
\end{tabular}

\section{Introduction}

The number of corporate sectors and company sub-sectors on the Indonesia Stock Exchange has become a very useful and important tool for investors in the company at this time. One of the sub-sectors that is of concern to researchers is the household equipment sub-sector, where there is a lot of turmoil in companies in the household appliance sub-sector. Each company certainly has many investors who contribute in the development of the company's business, where later each investor will get their respective dividends from the company. The number of investors who invest in a company will certainly maximize the company's performance in generating profits from shares invested by investors.

Earnings obtained from each share is called Earning per Share. According to Budiman (2018), Earning per Share is the company's net profit divided by the number of shares outstanding, so 
the results can be seen from the effectiveness of the Earning per Share of the company. In the activities of a company, of course the most attention is also their sales performance. Because every company certainly has the services or goods they sell or offer to their customers.

According to Kasmir (2016), sales growth is one part of the growth ratio that explains how the company's performance in maintaining its economic position amid economic turmoil and also comparison with similar sector companies. And companies will certainly always pay attention to whether the performance of their sales each year grows with good or not. The performance of earnings per share and also sales growth is an important component that will be examined in this study considering how these two things greatly affect stock prices and show the value of the company in the eyes of investors.

Reporting from Kabar Bisnis (2020) that one of the household appliance subsector companies namely Langgeng Makmur Industry has the determination or goal to increase their sales by 15 percent. In this case, the Langgeng Makmur company wants to focus their sales on the export market because they see the potential for increased sales growth, given that in 2018 Langgeng Makmur received sales of Rp 456 billion, where in 2017 they only received sales of Rp 411 billion. This shows the difference in sales increase of Rp 45 billion which gives positive performance results to the company Langgeng Makmur.

A company certainly wants to have a share price in accordance with their expectations and to maximize this, the company must ensure that every aspect of their financial statements has a good number. Earnings per Share and Sales growth are aspects that can be used to improve stock price performance. Judging from the two components of the variable, it is found that these two things have a correlation with stock prices how the profits from each share and also sales growth will have an effect on stock prices whether it is increasing or not.

Reporting from CNBC (2018), that in 2017 PT. Lasting Makmur suffered losses due to their export power fell and affected their income by $0.19 \%$. Where in 2016 , they posted a net profit of Rp. 6.9 billion but dropped in 2017 to a net loss of Rp. 31.14 billion. Another factor contributing to the decline in the financial performance of Langgeng Makmur was that their cost of goods sold increased by $6.71 \%$ to Rp. 330.35 billion compared to 2016 worth Rp. 309.58 billion. This is caused by the use of raw materials and also the increase in manufacturing costs which causes an increase in cost of goods sold. And of course, this will have an impact on the decline in earnings per share of the company, because Langgeng Makmur has to incur losses in 2017 so they have to rack their brains again so that the company's sales in the following year can reap profits. In analyzing the turmoil that occurs in the company, every potential investor who wants to invest must have consideration when they want to invest so that the decisions, they make provide security, profits and clarity for them. Therefore, investors must understand the analysis of the factors that influence the company's financial condition so that investors get a clear picture of the company's ability in the field.

A study of Financial Ratios and Sales Growth has been conducted by Widjaya, Widayanti and Colline (2016) in their research, namely the Effect of Financial Ratios (EPS \& ROE) and Sales Growth on Stock Prices in Manufacturing Companies on the Indonesia Stock Exchange in the period of 2011-2014 which prove that partially Earning Per Share (EPS) has a significant and positive effect on stock prices while Sales Growth has no significant effect on stock prices. While in a research journal conducted by Surya and Yusuf (2016) with the title Analysis of the Effects of Financial Ratios, Sales Growth and Dividends on Changes in Stock Prices in Consumer Goods Companies in the period 2011-2015 states that things are different in terms of Earning Per Share and Growth sales do not have a significant effect on stock prices. 
So, an understanding is obtained that to know changes in stock prices in a company can be predicted with the analysis of financial ratios namely Earnings per Share and also the Sales Growth Ratio.

\section{Literature Review}

\section{Earnings per Share}

According to Widoatmodjo (2015), Earning per share is the company's profit distributed to investors or shareholders. Meanwhile according to Salim and Slamet (2010: 82), "Earning per Share is profit earned by each share. A company that has good performance certainly also has the ability to benefit from its performance. "Therefore, in general, shareholders or commonly known as investors will certainly be very interested in investing in a company if the EPS produced by the company is high. Because Earning per Share is a factor in the company's success. According to Bringham (2009: 23), there are factors that can influence the rise or fall of earnings per share:

1. Factors causing the increase in Earning Per Share (EPS):

a. Net profit increased and the number of ordinary shares outstanding

b. Fixed net income and number of ordinary shares outstanding.

c. Net income rises and the number of ordinary shares outstanding decreases.

d. The percentage increase in net profit is greater than the percentage increase in the number of shares of common stock outstanding.

2. Factors causing decreased Earning Per Share (EPS):

a. Fixed net income and number of ordinary shares outstanding.

b. Net profit decreased and number of ordinary shares outstanding.

c. Net profit decreased and the number of ordinary shares outstanding rose.

The percentage decrease in net profit is greater than the percentage decrease in the number of shares of common stock outstanding.

\section{Sales Growth}

Sales growth is an increase or decrease turmoil seen from year to year through the company's income statement. And a healthy company can certainly be seen from year to year the significance of the increase in sales that will affect the company's profit increase Maryanti (2016). There are several factors that influence sales growth, namely sales conditions and capabilities, market conditions, capital, and organizational or company conditions that include how these factors can show the company's ability in their effectiveness to make an increase in sales Swastha (2005).

\section{Stock Price}

Stock prices are formed due to demand and supply formed by a mechanism in the capital market, if demand rises then stock prices tend to rise, conversely if supply surges then stock prices will fall, Sartono (2008). According to Brigham and Houston (2010: 33) there are several things that affect stock prices, namely internal and external factors, namely: 
1. Internal factors

a. Announcements about marketing production sales such as advertising, about of funding, such as announcements relating to equity and debt, the management board of directors such as changes and changes in directors, the management board of directors such as changes and changes in directors.

b. Labor announcements, such as new negotiations, new contracts, strikes and more.

c. Investment announcements such as expanding research development plants and closing other businesses.

d. Announcement of company financial statements, such as earnings per share (EPS), dividends per shere (DPS), Price Earnings Ratio, Net profit margins, return on assets (ROA) and others.

2. External factors

a. Announcements from the government such as changes in interest rates on deposits and foreign exchange rates, inflation, and various economic regulations and regulations issued by the government.

b. Legal announcements such as lawsuits against companies or against managers and company claims against managers.

c. Securities industry announcements, such as insider trading annual meeting reports, trading volume or stock price restrictions or trading delays.

Every investor will certainly see every factor that exists when they want to buy shares in a company and of course return again that the internal and external factors of a company are critical to their success in marketing their shares to investors, because every investor must always expect high returns or the best of the companies that they see are good opportunities for investment.

\section{Conceptual Framework}

Research on the effect of EPS and sales growth on stock prices on household appliances companies listed on the Indonesia Stock Exchange has the following framework:

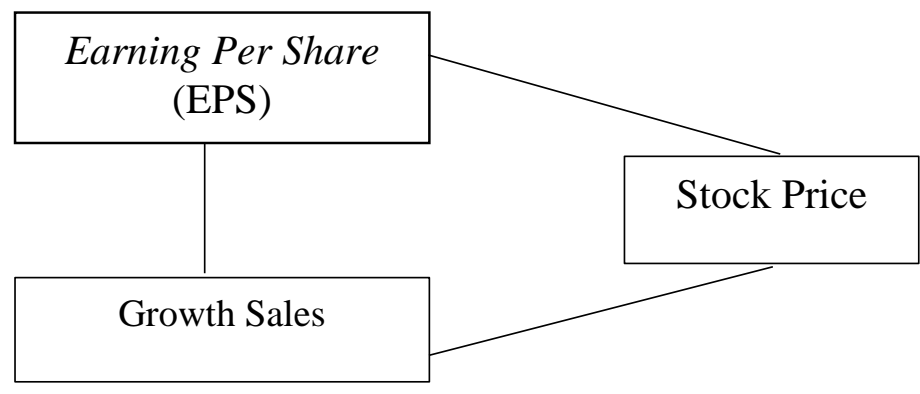


Research Hypothesis

The hypotheses in this study are as follows:

$\mathbf{H}_{1}$ : There is a significant effect between earnings per share on stock prices

$\mathbf{H}_{2}$ : There is a significant effect between sales growth on stock prices

\section{Research Methods}

\section{Population and Sample}

The population in this study is the consumer goods industry companies listed on the Stock Exchange from 2014 to 2019, which amounted to xx companies with samples for this research are household appliances subsector companies. While the sampling in this study is using purposive sampling technique. This sampling method is also called judgment sampling, which is based on certain considerations (Sanusi, 2011: 95). In order to obtain a sample of $x$ companies selected based on criteria.Characteristics of the sample used in this study are:

1. The companies sampled are household appliances sub-sector companies listed on the Indonesia Stock Exchange in 2014 - 2019

2. Household appliances sub-sector companies that publish annual reports and audited financial statements for the period $2014-2019$

3. Household appliances sub-sector companies that present data on the board of directors, independent commissioners for the period 2014-2019

Following is the sampling process table:

Table 1. Data collecting process

\begin{tabular}{ll}
\hline $\begin{array}{l}\text { Household appliances sub-sector companies listed on the } \\
\text { Stock Exchange in 2014 - 2019 }\end{array}$ & 5 \\
\hline $\begin{array}{l}\text { Household appliances sub-sector companies that were not } \\
\text { listed on the Indonesia Stock Exchange in 2014 - 2019 }\end{array}$ & 0 \\
\hline $\begin{array}{l}\text { The company did not issue audited financial statements in } \\
\text { the period } 2014 \text { - } 2019 \text { (no data were available regarding } \\
\text { the board of directors, independent commissioners, and } \\
\text { audit committees and return on asset data) }\end{array}$ & 2 \\
\hline Company Samples & $\mathbf{3}$ \\
\hline Research Year & $\mathbf{5}$ \\
\hline $\begin{array}{l}\text { Research Year } \\
\text { Total Samples }\end{array}$ & $\mathbf{1 5}$ \\
Source: Indonesian Exchange &
\end{tabular}

From the above table, it can be seen that 3 out of 5 household equipment sub-sectors listed on the Indonesia Stock Exchange in the period 2015 - 2019 met the sampling criteria in this study. So, there are a total of 12 company financial statements starting from 2015 - 2019 that the author will make as a research sample. 


\section{Dependent Variable}

The stock price is a determination of the value of shares determined by the company to be circulated to buyers of shares. Quarterly stock prices will differ depending on the income received by the company. And stock prices also have the highest price, lowest, to the closing price which is the average value of the stock price.

\section{Independent Variables}

Earnings per Share, Systematically Tandelilin (2010: 374) formulates:

$$
E P S=\frac{\text { Net Profit }}{\text { Number of Shares }}
$$

Sales Growth, Kasmir (2010: 137) states the formula for calculating Sales Growth is

G : Growth sales rate

$$
G=\frac{S I-S O}{S O} \times 100 \%
$$

SI : Total current sales

SO : Total sales for least period (total sales for the last period)

\section{Results}

Descriptive Analysis

Table 2. Descriptive Statistic Output



Source: Data processed

Descriptive Statistical Data can be said to be normally distributed if the results of the Skewness and Kurtosis values are close to zero. Based on SPSS data above the Skewness and Kurtosis values are $-1,396,-0,637,0.560$ and $1,952,-0,940,-1,345$, so it can be concluded that the data are normally distributed. 
Table 3. One-Sample Kolmogorov-Smirnov Test

\begin{tabular}{lll}
\hline & & Unstandardized Residual \\
\hline $\mathrm{N}$ & & 15 \\
Normal Parameters & Mean & .0000000 \\
& Std. Deviation & 101.63608135 \\
& Absolute & .187 \\
Most Extreme Differences & Positive & .187 \\
& Negative & -.138 \\
Kolmogorov-Smirnov Z & & .726 \\
Asymp. Sig. (2-tailed) & & .667 \\
\hline
\end{tabular}

a. Test distribution is Normal.

b. Calculated from data.

Data processed by the author with SPSS 21

Based on the data above, the significance value of Asymp. sig is 0.667 , which means it is greater than 0.05 . Then it can be concluded that the data above can be normally distributed.

Table 4. Heteroscedasticity Test

\begin{tabular}{|c|c|c|c|c|c|c|}
\hline \multicolumn{2}{|c|}{ Model } & \multicolumn{2}{|c|}{ Unstandardized Coefficients } & \multirow{2}{*}{$\begin{array}{c}\begin{array}{c}\text { Standardized } \\
\text { Coefficients }\end{array} \\
\text { Beta } \\
\end{array}$} & \multirow[t]{2}{*}{$\mathrm{t}$} & \multirow[t]{2}{*}{ Sig. } \\
\hline \multirow{4}{*}{1} & & & & & & \\
\hline & (Constant) & 86.782 & 12.907 & & 6.724 & .000 \\
\hline & EPS & .710 & .395 & .418 & 1.796 & .098 \\
\hline & Growth & -257.731 & 105.780 & -.567 & -2.436 & .031 \\
\hline
\end{tabular}

a. Dependent Variable: Abs_RES

Data processed by the author with SPSS 21

Based on the data above, the significance values of the two variables X1 and X2 exceed 0.05 and less than 0.05 . So, it can be concluded that each variable exists without heteroscedasticity and there is heteroscedasticity in the regression model.

Table 5. Multicolinearity Test

\begin{tabular}{|c|c|c|c|c|c|c|c|}
\hline \multirow[t]{2}{*}{ Model } & \multicolumn{2}{|c|}{$\begin{array}{l}\text { Unstandardized } \\
\text { Coefficients }\end{array}$} & \multirow{2}{*}{\multicolumn{2}{|c|}{$\begin{array}{l}\text { Standardized } \mathrm{t} \\
\text { Coefficients } \\
\text { Beta }\end{array}$}} & \multirow[t]{2}{*}{ Sig. } & \multicolumn{2}{|c|}{ Collinearity Statistics } \\
\hline & $\bar{B}$ & Std. Error & & & & Tolerance & VIF \\
\hline (Constant) & 346.134 & 28.947 & & 11.958 & .000 & & \\
\hline EPS & 1.554 & .886 & .462 & 1.754 & .105 & .946 & 1.057 \\
\hline Growth & -186.678 & 237.232 & -.207 & -.787 & .447 & .946 & 1.057 \\
\hline
\end{tabular}

a. Dependent Variable: Stock

The data above states the VIF values for variables $\mathrm{X} 1$ and $\mathrm{X} 2$ are respectively below 10.00. It can be concluded that in this data multicollinearity does not occur in the regression model. 
Table 6. Correlations Coefficient Test

\begin{tabular}{lllll}
\hline & & EPS & Growth & Stock \\
\hline \multirow{4}{*}{ EPS } & Pearson Correlation & 1 & .231 & .414 \\
& Sig. (2-tailed) & & .407 & .125 \\
& $\mathrm{~N}$ & 15 & 15 & 15 \\
& Pearson Correlation & .231 & 1 & -.100 \\
Growth & Sig. (2-tailed) & .407 & & .722 \\
& $\mathrm{~N}$ & 15 & 15 & 15 \\
& Pearson Correlation & .414 & -.100 & 1 \\
\multirow{5}{*}{ Stock } & Sig. (2-tailed) & .125 & .722 & \\
& $\mathrm{~N}$ & 15 & 15 & 15 \\
\hline
\end{tabular}

Based on the results of the Pearson Product Moment Correlation, it can be seen that testing the Earnings per Share variable with stock prices has a correlation value of $\mathrm{r}$ of 0.414 . This means that there is a low and positive relationship between earnings per share with sales growth. Testing the variable proportion between growth sales with stock prices shows a correlation value of $-0,100$. This means that there is a very low and negative relationship between the Proportion of the Board of sales growth and the Share Price.

Table 7. Coefficient of Determination

\begin{tabular}{llllll}
\hline Model & R & R Square & Adjusted R Square & $\begin{array}{l}\text { Std. Error of the } \\
\text { Estimate }\end{array}$ & \\
\hline 1 & $.461^{\mathrm{a}}$ & .212 & .081 & 109.77951 & \\
\hline a. Predictors: (Constant), Growth, EPS & & &
\end{tabular}

Through the above data it can be seen the results of $\mathrm{r} 2=0.212$, it can be concluded that the magnitude of the coefficient of determination is equal to $21.2 \%$. This figure implies that the variable EPS (X1) and Growth (X2) simultaneously influence $21.2 \%$ of the Share Price (Y). While the other $78.8 \%$ is influenced by other factors.

Table 8. Multiple Regression Analysis

\begin{tabular}{|c|c|c|c|c|c|c|}
\hline \multirow[t]{2}{*}{ Model } & & \multicolumn{2}{|c|}{ Unstandardized Coefficients } & \multirow{2}{*}{$\begin{array}{l}\text { Standardized } \\
\text { Coefficients } \\
\text { Beta }\end{array}$} & \multirow[t]{2}{*}{$\mathrm{t}$} & \multirow[t]{2}{*}{ Sig. } \\
\hline & & $\bar{B}$ & Std. Error & & & \\
\hline \multirow{3}{*}{1} & (Constant) & 346.134 & 28.947 & & 11.958 & .000 \\
\hline & EPS & 1.554 & .886 & .462 & 1.754 & .105 \\
\hline & Growth & -186.678 & 237.232 & -.207 & -.787 & .447 \\
\hline
\end{tabular}

a. Dependent Variable: Stock

Based on the table 8, the resulting regression equation Stock Price $=346,134+1.554$ EPS 186.67g. That is, the Earnings per Share regression coefficient has a positive effect on stock prices, where if the board of directors has increased, the return on assets will increase by 1,554. And the regression coefficient of the proportion of growth has a negative effect on stock prices, where if the proportion of sales growth decreases, ROA will increase 186,678. And simultaneously, the Earning Per Share variable and the proportion of sales growth does not have a positive influence on the value of ROA, meaning that if the Earning Per Share together 
and the proportion of sales growth increase, it does not significantly influence the stock price increase.

Table 9. t-test

\begin{tabular}{lllllll}
\hline Model & & \multicolumn{2}{l}{ Unstandardized Coefficients } & $\begin{array}{l}\text { Standardized } \\
\text { Coefficients }\end{array}$ & $\mathrm{t}$ & Sig. \\
\cline { 3 - 5 } & & $\mathrm{B}$ & Std. Error & Beta & \\
\hline \multirow{3}{*}{1} & (Constant) & 346.134 & 28.947 & & 11.958 & .000 \\
& EPS & 1.554 & .886 & .462 & 1.754 & .105 \\
& Growth & -186.678 & 237.232 & -.207 & -.787 & .447 \\
\hline
\end{tabular}

a. Dependent Variable: Stock

Based on the data above, it can be seen that the significance value of $X 1$ is $0.105>0.05$, it can be concluded that there is no effect of $\mathrm{X} 1$ on $\mathrm{Y}$.

Table 10. ANOVA

\begin{tabular}{lllllll}
\hline Model & & Sum of Squares & df & Mean Square & F & Sig. \\
\hline \multirow{3}{*}{1} & Regression & 38927.098 & 2 & 19463.549 & 1.615 & $.239^{\mathrm{b}}$ \\
& Residual & 144618.502 & 12 & 12051.542 & & \\
& Total & 183545.600 & 14 & & & \\
\hline
\end{tabular}

a. Dependent Variable: Stock

b. Predictors: (Constant), Growth, EPS

Based on the data above, it can be seen that the $X 2$ significance value of $0.239>0.05$, it can be concluded that there is no effect of $\mathrm{X} 2$ on $\mathrm{Y}$.

\section{Conclusions and Recommendations}

Based on the results of the analysis and discussion described in the previous section, the authors conclude that in this study:

1. Earnings per Share (EPS) has a positive but not significant effect on the share prices of the household appliances sub-sector companies listed on the Indonesia Stock Exchange in the period 2015 - 2018. This is evidenced by the regression coefficient X1 of 1.554 and a significance value of 0.105 . So if there is an increase in Earning per Share (EPS) in the household equipment sub sector, it will not affect the stock price.

2. Sales growth has a negative and not significant effect on the stock prices of companies in the household appliances sub-sector listed on the Indonesia Stock Exchange in the period 2015 - 2018. This is evidenced by the regression coefficient X1 -186,678 and a significance value of 0.447 . So that if there is an increase in sales growth in the household appliances sub-sector, it will not affect the stock price.

Adjusted R2 test results in this study amounted to 0.212. This shows that the share price of household appliances sub-sector companies listed on the Indonesia Stock Exchange in the period of 2015 - 2018 was influenced by $21.2 \%$ by EPS and sales growth. 


\section{Suggestions}

Based on the results of the study found several things that can be used as suggestions:

a. According to the authors, similar topics are recommended to be studied further by including other independent variables, such as return on assets, interest rates and other external factors, considering that R2 in this study is only $21.2 \%$

b. In addition to including other independent variables in further research, it is necessary to also increase the sample of research so that the amount of data is greater

\section{References}

Abdurrahman, A., Salim, M. A., \& Slamet, A. R. (2017). PENGARUH DIVIDEND PER SHARE (DPS), NET PROFIT MARGIN (NPM) DAN RETURN ON EQUITY (ROE) TERHADAP HARGA SAHAM (Perusahaan Industri Manufaktur yang tercatat di Bursa Efek Indonesia Periode 2012-2015. Jurnal Ilmiah Riset Manajemen, 6(5), 190-202.

Anwar, S. (2011). Metodologi Penelitian Bisnis. Jakarta: Salemba Empat.

Brigham, E. F., \& Joel, F. Houston,(2001) Fundamentals of Financial Management. Alih Bahasa Dodo Suharto dan Herman Wibowo, Manajemen Keuangan, Edisi Kedelapan, Buku Satu, Erlangga, Jakarta.

CNBC Indonesia (2018). https://www.kabarbisnis.com/read/2892464/bidik-penjualantumbuh-15-persen-langgeng-makmur-genjot-pasar-ekspor

Kasmir, (2016). Analisis Laporan Keuangan. Jakarta: PT. RajaGrafindo Persada

Kasmir. (2011). Analisis Laporan Keuangan. Jakarta: Kencana Pernada Media Group

Maryanti, E. (2016). Analisis Profitabilitas, Pertumbuhan Perusahaan, Pertumbuhan Penjualan dan Struktur Aktiva terhadap Struktur Modal pada Perusahaan Sektor Industri Barang Konsumsi yang terdaftar di Bursa Efek Indonesia (Studi Empiris pada Perusahaan Manufaktur yang Terdaftar di Bursa Efek Indonesia Tahun 20122014). Riset Akuntansi dan Keuangan Indonesia, 1(2), 143-151.

Salim, J., \& Kom, S. (2010). Cara gampang bermain saham. Visimedia.

Sanusi, A. (2011). Metodologi Penelitian Bisnis, Jakarta. Salemba empat

Surya, Y. Y. A. (2016). Analisis Pengaruh Rasio Keuangan, Pertumbuhan Penjualan Dan Dividen Terhadap Perubahan Harga Saham Perusahaan Consumer Goods. Kajian Bisnis Sekolah Tinggi Ilmu Ekonomi Widya Wiwaha, 24(2), 181-195.

Widioatmodjo, S. (2015). Pengetahuan Pasar Modal untuk Konteks Indonesia. Elex Media Komputindo.

Widjaya, J. S. (2016). Pengaruh Rasio Keuangan Dan Pertumbuhan Penjualan Terhadap Harga Saham Perusahaan Manufaktur Yang Terdaftar Di Bursa Efek Indonesia. Ilmiah Manajemen Bisnis. 